ISSN: 1907-7262, E-ISSN: 2477-5339

Volume 10, Nomor 1, Juni 2019

http://journal.stainkudus.ac.id/index.php/yudisia/index

\title{
Tes Kesehatan Sebagai Syarat Pra Nikah (Studi UU Pernikahan di Kuwait)
}

\author{
Lathifah Munawaroh \\ UIN Walisongo \\ lathifah.munawaroh@walisongo.ac.id
}

\begin{abstract}
The healthiness is often not a portion of attention in preparation for marriage. It can be seen from the absence of legislation in this country, nor in Kompilasi Hukum Islam or in the Marriage Law. The discussion of Pre-marital check up is also not found in the Fiqh books as one of the pre requisites of marriage. In Indonesia, Toksoid Tetanus Immunization have been applied for prospective brides to prevent Tetanus, tuberculosis, Differi, whooping cough and measles, but it can not know maximally the medical history of prospective mates and sexually transmitted diseases and descendants, such as HIV/AIDS and the growing epidemic; Thalassemia. Pre-marital check up for couples is one of the solutions to the increasing numbers of disease prevention. The harmoniy of the marriage with the presence of healthy marriage. And this is the one of the maqashid al-shariah. This research is the literature study, and gives a result: this practice has been implemented by many countries, one of them in Kuwait who apply this rule as one example to be able to consider its application in Indonesia. The implementation is ijtihadiyyah, which can be changed in accordance with condition and the background.
\end{abstract}

Keywords: Pre-marital check up, marriage, maqashid al-shariah

Abstrak: Kesehatan sering tidak mendapat porsi perhatian dalam persiapan perkawinan. Hal ini dapat dilihat dari ketiadaan peraturan perundang-undangan tentang ini baik dalam KHI ataupun UU Perkawinan. Ditambah pula dalam fiqih klasik pun tidak ditemukan pembahasan tes kesehatan sebagai salah satu syarat pra nikah. Di Indonesia telah diterapkan Imunisasi Tetanus Toksoid bagi calon pengantin perempuan untuk mencegah Tetanus, TBC, Differi, Batuk Rejan dan Campak, tidak dapat mengetahui riwayat kesehatan calon pasangan dan penyakit menular seksual dan keturunan, seperti HIV/AIDS dan Thalasemia yang semakin mewabah dengan angka yang semakin meningkat pada tiap tahunnya. Tes kesehatan bagi pasangan yang akan menikah menjadi salah satu solusi pencegahan bertambahnya angka penyakit ini, karena tes kesehatan lebih komprehensif. Keharmonisan rumah tangga dengan kehadiran keturunan sehat dari rumah tangga yang sehat pula. Pemeliharaan keturunan menjadi salah satu bagian dari Maqashid al-Syariah. Penelitian ini bersifat study literature, dan memberikan sebuah hasil: Praktek ini telah diterapkan oleh banyak negara, salah satunya di Kuwait yang menerapkan peraturan ini sebagai salah satu contoh untuk dapat dipertimbangkan 
penerapannya di negara Indonesia. Tentu penerapan ini bersifat ijtihadiyyah, yang dapat berganti sesuai dengan kondisi yang malatarbelakangi.

Kata Kunci: tes kesehatan pra-nikah, pernikahan, maqashid al-syariah

\section{Pendahuluan}

Salah satu tujuan pernikahan yang merupakan bagian dari maqāṣid alshari'ah adalah hifzu al-nasl yaitu menjaga keturunan dan melindunginya sehingga terbentuk keturunan yang sehat baik secara jasmani ataupun rohani. Sehat secara jasmani dalam pengertian sehat dari penyakit-penyakit menular maupun penyakit keturunan. Hal ini dapat berhasil jika para calon pengantin mempersiapkan dari awal hal-hal yang terkait tentang kesehatan diri sendiri. Kesuksesan atau kegagalan pernikahan pun tergantung pada cara yang ditempuh dalam memilih pasangan hidupnya, ketepatan dalam memilih pasangan hidup serta melihat, menyelidiki dan mengenal kepribadian pasangan yang akan dinikahinya. Ini menjadi landasan awal dalam mengarungi bahtera rumah tangga, agar kelak dapat merasakan keserasian dan keharmonisan. Maka dari itu, melihat dan menyelediki calon pasangan juga menjadi salah satu faktor yang perlu dipertimbangkan baik tentang riwayat kesehatannya ataupun kehidupannya dan kepribadiannya. Namun, seringnya kesehatan jarang menjadi tolak ukur dalam melangkah ke perkawinan. Hal ini juga dapat dilihat dari tidak adanya Undang-Undang yang mengatur tentang persiapan pernikahan dari segi kesehatan, baik Undang-Undang Perkawinan ataupun Kompilasi Hukum Islam. Dalam fiqih pun, tidak dijelaskan secara eksplisit tentang syarat kesehatan sebagai salah satu syarat pernikahan.

Namun dalam prakteknya, di Indonesia telah diterapkan Imunisasi Tetanus Toksoid bagi calon pengantin. Pelaksanaannya berdasarkan kepada Instruksi Bersama Direktur Jenderal Bimbingan Masyarakat Islam dan Urusan Haji Departemen Agama dan Direktur Jenderal Pemberantasan Penyakit Menular dan Penyehatan Lingkungan Pemukiman Departemen Kesehatan No : 02 Tahun 1989 Tentang Imunisasi Tetanus Toksoid Calon Pengantin dan sebagai dasar dari pelaksanaan UU no. 1 tahun 1974 tentang perkawinan dan Peraturan Pemerintah no. 9 tahun 1975 tentang pelaksanaan UU no. 1 tahun 1974, serta Instruksi Presiden RI no .1 tahun 1991 tentang Kompilasi Hukum Islam. Berdasarkan hal ini maka calon pasangan wanita diwajibkan melakukan suntik Imunisasi Tetanus Toksoid ketika akan melakukan perkawinan dengan melampirkan bukti atau surat keterangan sudah melakukan Imunisasi Tetanus Toksoid bersama persyaratan yang lain ke Kantor Urusan Agama (KUA). Hal ini bertujuan setiap calon pasangan wanita ataupun bayi yang akan dilahirkannya kelak terbebas dari infeksi tetanus. Hanya saja imunisasi atau vaksin jenis ini hanya dapat mencegah 
infeksi Tetanus, TBC, Differi, Batuk Rejan dan Campak dan tidak bisa untuk mengetahui riwayat kesehatan calon pasangan dan penyakit menular seksual dan keturunan, seperti HIV/AIDS dan Thalasemia yang semakin mewabah di masyarakat kita. Jumlah penderita talasemia mayor di Tanah Air terus mengalami peningkatan. Ketua Yayasan Thalassemia Indonesia, Ruswadi, menyebut jumlah penderita talasemia mayor yang ditandai dengan kebutuhan transfusi darah secara rutin saat ini sudah mencapai 7.238 penderita. Dari jumlah ini Jawa Barat merupakan peringkat pertama, diikuti oleh Jawa Tengah, lalu Jawa

Timur (http://nasional.republika.co.id/berita/nasional/daerah/16/05/19/o7f2n4284jumlah-penderita-thalassemia-terus-meningkat, di akses pada 01/10/2017). Sementara jumlah penderita HIV dari tahun 1984 hingga 2012 tercatat 150.296 orang menurut Pusat Data dan Informasi pada kementrian kesehatan RI pada tahun 2014. Angka yang semakin meningkat pada tiap tahunnya ini sudah sepatutnya menjadikan pemerintah mengambil kebijakan-kebijakan untuk membebaskan masyarakat dari penyakit-penyakit di atas.

Dari sini, tes kesehatan pra nikah sudah seharusnya ada, dan tidak hanya sekedar imunisasi satu jenis saja, namun sudah selayaknya merambah ke tes pemeriksaan yang lainnya seperti pemeriksaan terkait penyakit keturunan atau penyakit menular lainnya. Karena tes ini bertujuan membentuk keluarga sehat sejahtera dengan mengetahui kemungkinan kondisi kesehatan anak yang akan dilahirkan (riwayat kesehatan kedua belah pihak), termasuk soal genetik, penyakit kronis, penyakit infeksi yang dapat mempengaruhi kondisi kesehatan keturunan. Dengan ini melakukan pemeriksaan kesehatan pranikah berarti kita telah melaksanakan pemeliharaan keturunan (hifẓu al-nasl) yang diperintahkan oleh agama.

Kuwait, adalah salah satu dari sekian Negara yang mempunyai aturan tes kesehatan pra pernikahan berdasarkan UU no.31 Tahun 2008. Sehingga di sana pernikahan tidak akan dapat dicatatkan tanpa melampirkan hasil pemeriksaan kesehatan pra nikah yang dikeluarkan oleh Kementrian Kesehatan setempat, mengingat dua penyakit di atas khususnya yang banyak di alami oleh masyarakat Kuwait. Tentu dalam pelaksanaanya memiliki mekanisme tersendiri, dimana calon pasangan tidak terikat dengan hasil cekup tersebut, namun mereka masih diberikan kebebasan meneruskan pernikahan dengan menandatangi resiko yang mungkin akan dihadapi, atau menghentikan pernikahan sebatas ta'aruf saja.

Adapun tujuan dari penulisan artikel ini ialah untuk mendeskripsikan pentingnya tes kesehatan sebagai syarat pra nikah terkait studi UU pernikahan di Kuwait. 


\section{Kajian Literatur \\ Pernikahan dan Pemilihan Jodoh}

Dalam agama Islam pernikahan adalah sebuah kesunnahan dan merupakan perintah Allah. Bahkan, menurut Amir terdapat 85 lebih ayat alQuran di antara lebih dari 6000 ayat yang tersebar dalam 22 surat dari 114 surat (Amir Syarifudin, 2014: 6). Tidak hanya itu, Terdapat dua kitab hadis popular yang secara khusus membahas tentang hukum, yaitu pertama: kitab Muntahā al-Akhbār karya Ibnu Taimiyah dengan syarah oleh al-Syaukāni dalam kitabnya Nail al-Awțār,. kedua: kitab Bulugh al-Maram yang merupakan karya Ibnu Hajar al-'Asqalāni dengan syarah al-Shan'any dalam kitabnya Subul al-Salām. Dalam kitab pertama terdapat sekitar 330 hadis tentang perkawinan, sementara dari kitab kedua sekitar 175 hadis (Amir Syarifudin, 2014: 13). Bahkan syariat nikah ini merupakan salah satu garis dari empat garis penataan ajaran fikih, dikarenakan pada batang tubuh ajaran fikih terdapat empat garis penataan: rub' al-'Ibādāt, rub' al-Mu'āmalāt, Rub' al munākahāt, dan Rub' al-jināyāt (Lihat Ali Yafie, 1982: 1).

Pada dasarnya, manusia secara kodratnya mengalami fase kehidupan. Fase usia kanak-kanak, ia belajar memahami lingkungan sekitar dan tempat ia tinggal. Berikutnya fase remaja ia mulai mencari jati dirinya. Lalu pada fase dewasa ia merencanakan masa depannya, menikah dan memiliki keluarga. Pada masa dewasa awal ini terdapat tugas-tugas yang harus ia emban. Di antara tugas-tugas perkembangan dewasa awal seperti yang dikemukakan oleh Havigurst adalah: Pertama, Mencari dan menemukan calon pasangan hidup. Kedua, Belajar hidup bersama pasangan. Ketiga, Membina kehidupan rumah tangga. Keempat, Membesarkan anak. Kelima, Mengurus rumah. Keenam, Meniti karier dan pekerjaan. Dari sini difahami bahwa memilih pasangan lalu menikah adalah salah satu di antara tugas perkembangan yang harus dialami oleh tiap individu pada masa dewasa awal (Agoes Dariyo, 2003: 105). Dalam menghadapi tugas perkembangan dewasa awal ini maka tiap individu akan berhadapan dengan persiapan pernikahan berupa pemikiran dan perasaan dalam memutuskan antara menikah atau menuda, persiapan waktu yang tepat untuk menikah, persiapan keuangan, dan persiapan kesehatan ataupun persiapan seks hingga kemudian antara individu yang telah menikah diharuskan belajar memehami peran baik sebagai suami ataupun istri.

Menurut bahasa dalam literatur fiqh berbahasa arab perkawinan disebut dengan dua kata: nikāh ( زكاح ) dan zawāj ) darti penggabungan dan percampuran. Adapun definisi istilah, para ulama menyebutkan definisi yang berbeda namun berinti sama. Sebagian menyebutkan definisi nikah adalah: akad serah terima antara laki-laki dan perempuan dengan tujuan untuk saling memuaskan satu sama lainnya dan 
untuk membentuk sebuah bahtera rumah tangga yang sakinah serta masyarakat yang sejahtera (Tihami dan Sohari: 8). Menurut Ghandūr yang disadur oleh Amir Syarifuddin definisi pernikahan adalah akad yang menimbulkan kebolehan bergaul antara laki-laki dan perempuan dalam tuntutan naluri kemanusiaan dalam kehidupan dan menjadikan untuk kedua pihak secara timbal balik hak-hak dan kewajiban-kewajiban (Amir Syarifudin: 13). Sementara beberapa pakar Indonesia di antaranya Zakiyah Drajat, dkk mendefinisikan pernikahan adalah akad yang mengandung ketentuan hukum kebolehan hubungan kelamin dengan lafadz nikah atau tazwij atau yang semakna dengannya. Sedangkan Sajuti Thalib mendefinisikan perkawinan adalah suatu perjanjian suci kuat dan kokoh untuk hidup bersama secara sah antara seorang laki-laki dengan seorang perempuan membentuk keluarga yang kekal, santu menyantuni, kasih mengasihi, tentram dan bahagia (Zakiyah Darajat: 1985: 48).

Undang-Undang Perkawinan No.1 Tahun 1974 menyebutkan bahwa "Pernikahan adalah ikatan lahir bathin antara seorang pria dan seorang wanita sebagai suami istri dengan tujuan membentuk keluarga (rumah tangga) yang bahagia dan kekal berdasarkan Ketuhanan Yang Maha Esa”. Selain definisi yang diberikan oleh UU no.1 Tahun 1974, secara khusus dalam pasal 2 Kompilasi Hukum Islam (KHI) di Indonesia juga menyebutkan definisi lain yang hampir sama dengan tidak mengurangi arti definisi dari UU no.1 Tahun 1974 yaitu: Perkawinan menurut Islam adalah pernikahan yaitu akad yang sangat kuat atau mitsaqan ghalidzan untuk menaati perintah Allah dan melaksanakannya merupakan ibadah. Dalam definisi ini disebutkan lafal "akad yang sangat kuat atau mitsaqan ghalidzan" menguatkan definisi yang tersebut dalam UU perkawinan "Pernikahan adalah ikatan lahir bathin", kata "mitsaqan ghalidzan" diambil dari firman Allah pada surat al-Nisa: 21. Sementara lafal "untuk menaati perintah Allah dan melaksanakannya merupakan ibadah" dalam definisi KHI menguatkan lafal dalam definisi UU Perkawinan "berdasarkan Ketuhanan Yang Maha Esa". Dengan ini jelas bahwa pernikahan adalah peristiwa agama dan pelaksananya terhitung telah melakukan ibadah (Amir Syarifudin: 39-40).

Adapun hukum pernikahan, secara umum terjadi kesepakatan bahwa pernikahan adalah sebuah anjuran dan pelaksanaannya adalah dinilai ibadah dalam agama Islam. Wahbah al-Zuhaily menyimpulkan hukum nikah dari madzhab klasik bahwa pernikahan memiliki empat hukum yang berbeda dikarenakan perbedaan kondisi dan situasi. Pernikahan menjadi wajib jika seseorang telah siap nikah dan dapat menjalankan hak-kewajiban nikah, serta dia takut jika jatuh dalam kemaksiatan, sementara ia tidak dapat menjaga dirinya dari kemaksiatan dengan sarana lain seperti puasa. Di sini berlaku sebuah kaidah: Ma Lā Yatimmul Wājib Illā Bihī Fa Huwa Wājib yang berarti 
Perkara yang menjadi penyempurna dari perkara wajib, hukumnya juga wajib. Pernikahan menjadi haram jika seseorang yakin bahwa dirinya akan mendholimi istrinya karena tidak mampu untuk memberikan nafkah atau ia tidak dapat berlaku adil jika menikah dengan yang lainnya. Di sini berlaku sebuah kaidah mā addā ilā al-ḥarām fa huwa ḥarām yang berarti sesuatu yang dapat menjatuhkan kepada keharaman, maka sesuatu itu hukumnya haram.

Dalam realitanya, seseorang jika hendak menikah maka seseorang baik laki-laki atau perempuan memiliki motivasi tertentu dalam menentukan pasangannya. Dan ini pun sah-sah saja. Sebagian menjadikan kecantikan atau ketampanan sebagai salah satu motivasinya, sebagian yang lain kesuksesan dalam masalah perekonomian menjadi salah satu motivasi untuk memilih pasangannya. Dalam hal ini Nabi telah memberikan panduannya dalam sebuah hadisnya dengan riwayat dari Abu Hurairah, Nabi bersabda: "Perempuan dinikahi karena empat faktor. Karena hartanya, nasabnya, kecantikannya dan karena agamanya. Maka menangkanlah wanita yang mempunyai agama, engkau akan beruntung." (HR Bukhari dan Muslim)

Proses berikutnya khitbah atau peminangan yang merupakan pendahuluan dari transaksi nikah. Khitbah adalah penyampaian kehendak untuk menikahi seseorang. Tentang pelaksanaan khitbah, maka cara ataupun prosesnya beragam, dan tidak ada aturan yang spesifik dalam fiqih Islam. Proses ini bertujuan untuk lebih menguatkan ikatan perkwinan yang diadakan sesudahnya. Hal ini dikarenakan dengan khitbah, kedua calon dapat saling mengenal di antara keduanya. Karena pernikahan adalah ikatan sakral untuk selama-lamanya, maka hendaknya keduanya tidak tergesa-gesa. Hendaklah menyeleksi dengan benar tentang pilihannya, mengetahui karakter masingmasing, akhlak dan tabiatnya sehingga keduanya melaksanakan pernikahan dengan penuh cinta dan kasih sayang. Ini pula merupakan salah satu hikmah dianjurkan khitbah (Abdul Aziz Muhamad Azzam: 10). Khitbah atau peminangan ini sifatnya tidak mengikat. Khitbah adalah janji ingin menikah. Khitbah ini bukanlah akad nikah. Perjanjian yang sifatnya tidak mengikat. Bahkan andaisaja dalam perjanjian ini telah terjadi kesepakatan tentang kadar mahar, atau bahkan telah terjadi penyerahan hadiah-hadiah atau bahkan mahar, semua ini tidak menggeser status perjanjian ini. Sehingga dalam khitbah ini dapat saja terjadi pembatalan baik dari pihak perempuan atau lakilaki jika terdapat maslahat dalam pembatalannya. Namun tentu jika terjadi pembatalan hendaklah dilakukan pembatalan secara baik-baik. 


\section{Perkawinan: Rukun dan Syarat}

Diskursus tentang rukun dan syarat perkawinan menjadi permasalahan yang cukup unik dimana para fuqaha dan pakar berbeda pendapat tentang mana yang merupakan rukun dan mana yang menjadi syarat. Sebagian mengatakan sesuatu sebagai rukun, sebagian yang lain mengatakannya sebagai sebuah syarat. Perbedaan ini terjadi karena perbedaan pandangan dalam melihat inti ataupun focus dari sebuah perkawinan. Bila melihat UU Perkawinan, maka di dalamnya tidak berbicara tentang rukun perkawinan, namun hanya membicarakan syarat-syarat perkawinan dan syarat-syarat tersebut berkaitan dengan unsur-unsur atau rukun perkawinan. Sedangkan KHI dalam pasal 14 secara jelas membicarakan rukun perkawinan dengan mengikuti madzhab Syafiiyyah dan tidak memasukkan mahar sebagai rukun (Amiur Nurudin dan Azhari Akmal: 67).

Terlepas dari perbedaan istilah yang ada, terdapat empat rukun perkawinan menurut Jumhur ulama' dan masing-masing rukun memiliki syarat-syarat yang harus dipenuhi (Amiur Nurudin dan Azhari Akmal: 6263), keempat rukun tersebut adalah: Sepasang calon yang terdiri calon suami dan calon istri, wali nikah, dua orang saksi laki-laki, akad nikah. Walaupun mahar bukan merupakan rukun pernikahan, namun semua sepakat bahwa mahar adalah wajib dalam sebuah pernikahan. Banyak literatur fiqih menuliskan secara tersendiri tentang masalah mahar dan menuliskannya dengan istilah "Al Shodāq" sehingga akan kita temukan "Kitāb Al Shodāq" atau "Bāb Al Shodāq", atau "fashlun fì Al Shodāq (Al Māwardi, Al Hāwi Al Kabīr, 199: 390). Pemberian mahar ini sifatnya adalah pemberian yang pertama seorang suami kepada istrinya pada waktu akad nikah, yang menandakan bahwa di sana akan ada kewajiban-kewajiban meteri yang berikutnya selama masa hubungan pernikahan setelah pembayaran mahar. Dengan adanya pembayaran mahar ini suami dipersiapkan untuk menghadapi kewajiban-kewajiban yang sifatnya materi pada tahap berikutnya (Amir Syarifuddin: 87).

Pada prakteknya secara tertulis, kafaah tidak termasuk dalam syarat ataupun rukun nikah, kecuali kafaah dalam agama saja, yaitu agama Islam. Namun selain dalam masalah agama, maka syariat juga menganjurkan untuk memilih pasangan yang sekufu: dalam hal pendidikan dan strata social, supaya lebih dapat mencapai tujuan pernikahan itu sendiri. Diharapkan dengan adanya kafaah antara suami istri, maka pernikahan akan dapat berjalan dengan harmonis, dan langgeng. Sehingga oleh Jumhur ulama, kafaah di sini adalah sesuatu yang dianjurkan dan tidak termasuk dalam syarat sahnya pernikahan. Kafaah ini akan dapat menguatkan perjalanan pernikahan. Sehingga kafaah ini adalah merupakan hak istri. Meskipun disini 
kafaah tidak termasuk dalam bagian syarat ataupun rukun pernikahan, namun kedudukannya sebatas dianjurkan saja demi kelangsungan pernikahan supaya dapat berjalan dengan harmonis dan penuh keseimbangan (Wahbah alZuhaily: 6739). Dengan ini maka kafaah termasuk salah satu hal yang dianjurkan dalam pernikahan karena bertujuan salah satunya supaya pernikahan yang dibangun menjadi pernikahan yang harmonis, bahagia, bersinergi antara pasangan suami istri dimana kewajiban dan hak akan dapat berjalan secara seimbang. Kafaah ini bertujuan pula supaya pernikahan lebih seimbang, dengan keseimbangan ini perkawinan akan lebih langgeng. Namun sebaliknya, jika tidak seimbang, jika tidak sesuai kemungkinan yang muncul adalah problematika yang dapat berujung pada perceraian. Sehingga kafaah ini sebuah anjuran walau tidak menentukan sah/tidaknya sebuah pernikahan.

\section{PEMBAHASAN}

\section{Praktek Tes Kesehatan Pra Nikah di Kuwait.}

Dalam Undang-Undang Dasar Negara Kuwait, pada pasal kedua disebutkan bahwa agama resmi Negara Kuwait adalah Agama Islam. Sementara penentuan perundangan-undangan adalah menggunakan syari'at Islam sebagai sumbernya (Undang-Undang Dasar Kuwait terbit pada tahun 1962). Adapun peraturan tentang perkawinan pada Negara ini di atur oleh Undang-Undang No. 51 Tahun 1984 tentang al-Ahwal al-Syakhsiyyah dengan jumlah pasal 347 butir, dengan 96 butir pasal tentang pernikahan yang kesemua pasal ini bersumber dari syariat Islam sesuai dengan yang dinash-kan pada Undang-Undang Dasar Negara ini.

Pernikahan dalam hukum positif di Kuwait yaitu hukum positif yang mengacu pada Undang-Undang No. 51 tahun 1984 tentang Hukum Keluarga. Pada pasal-pasalnya mengatur hal-hal yang terkait dengan pernikahan salah satunya. Namun pada Undang-undang tersebut belum adanya kewajiban tes kesehatan sebagai syarat menikah di negeri Kuwait. Adapun tes kesehatan sebagai syarat pra nikah ini adalah peraturan yang lahir 22 tahun setelah Undang-Undang di Kuwait tentang hukum keluarga. Praktek tes kesehatan pra nikah di Kuwait berdasarkan pada UU No. 31 Tahun 2008, yang merupakan salah satu seperangkat penguat dari UU No. 51 Tahun 1984 tentang Hukum Keluarga di Kuwait. UU No. 31 Tahun 2008 ini terdiri dari enam pasal saja.

Perundangan ini pada dasarnya telah disetujui oleh Majlis al-Ummah sejak bulan November 2008, namun baru dapat dipraktekkah pada bulan Agustus pada tahun berikutnya, 2009 (https://www.alanba.com.kw/ar/kuwait-

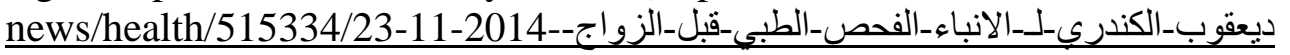
- (بحمي_الاجيال_القادمة_الامر اض-ويمنع_الزواج_غير-الامن undangan ini yaitu: 
Pasal Pertama: Bagi siapa saja yang ingin melakukan proses pernikahan, maka diharuskan melakukan tes kesehatan yang kemudian membawa surat bukti bahwa mereka bebas dari penyakit-penyakit genetika dan penyakit menular yang diputuskan oleh Kementrian Kesehatan. Dalam surat keterangan ini diterangkan bahwa pernikahan ini fit/aman atau tidak, dan berlaku 6 bulan sejak diterbitkannya.

Pasal Kedua: Bagi pihak KUA atau yang berwenang tidak boleh mencatat perkawinan hingga calon pengantin menyerahkan surat keterangan yang tersebut pada pasal pertama. Jika hasil dari surat keterangan ternyata tidak fit, maka wajib melampirkan pula surat pernyataan persetujuan dari kedua calon bahwa keduanya mengetahui hal ini. Dan persetujuan wali tidak sah jika si calon belum mencapai usia "al rusyd'.

Pasal Ketiga: Kementrian Kesehatan yang menentukan jenis-jenis cek kesehatan yang diperlukan terkait persiapan pernikahan, dan mensosialisasikan 3 bulan sejak terbitnya Undang-Undang ini.

Pasal Keempat: Bagi siapa saja yang membocorkan rahasia hasil dari cek kesehatan yang dimaksud pada pasal satu, maka ia akan mendapatkan denda penjara selama 1 tahun dan membayar denda sebanyak $1000 \mathrm{KD}$, atau salah satu dari keduanya.

Pasal Kelima: Pihak yang berwajib untuk mencatat pernikahan jika melanggar pasal kedua maka ia akan mendapatkan denda penjara selama 1 tahun dan membayar denda sebanyak $1000 \mathrm{KD}$, atau salah satu dari keduanya.

Pasal Keenam: Bagi perdana menteri dan unsur-unsur terkait harus melakukan peraturan ini terhitung sejak 6 bulan dari masa sosialisasi peraturan ini.

Dalam prakteknya, di Negara Kuwait ini pelaksanaan cek pra nikah ini dilaksanakan di klinik-klinik tertentu yang telah ditunjuk oleh Kementrian Kesehatan setempat pada tiap daerah di Kuwait. Dan tes kesehatan ini berlaku bagi warga Negara Kuwait baik laki-laki atau perempuan yang hendak menikah, peraturan ini tidak berlaku bagi warga pendatang kecuali jika mereka hendak menikah dengan warga Kuwait. Adapun rangkaian cek up di sini adalah rangkaian tes kesehatan untuk mengetahui penyakitpenyakit di bawah ini:

a. Penyakit-penyakit menular, yaitu: HIV, HBV (Hepatitis B), HBC (Hepatitis C), dan Sepilis

b. Penyakit-penyakit genetika turunan, yaitu: Thalassemia, dan Penyakit Sel Sabit (sickle cell anemia).

Pelaksanaan cek kesehatan ini memang merupakan salah satu program yang wajib, dan difasilitasi oleh Negara, sehingga semuanya tanpa Yudisia Vol. 10 No. 1, Juni 2019 
pungutan biaya. Ini yang menjadikan program ini berjalan dengan lancar. Tes kesehatan ini penting untuk dilakukan karena akan menyingkap penyakitpenyakit turunan. Karena pada dasarnya, seseorang bisa jadi "carrier" pembawa suatu jenis penyakit yang dapat menyebabkan ia melahirkan keturunan yang tidak sehat, namun padanya tidak terlihat keluhan apa-apa. Si pembawa penyakit ini bukan berarti ia seorang yang tidak normal tidak boleh nikah, namun justru ia dianjurkan menikah dengan seseorang yang terbukti sehat tidak membawa penyakit, sehingga keduanya baik suami/istri bukan dari pembawa penyakit yang dapat mengakibatkan keturunan yang tidak sehat. Salah satu tujuan penting cek kesehatan ini adalah memastikan kesehatan kedua calon yang akan menikah dari penyakit-penyakit yang mudah menular antara keduanya dengan adanya pernikahan, serta pengambilan tindakan pengobatan dengan cara cepat. Jadi di sini terdapat tiga kategori jenis orang: seorang yang sehat, seorang yang carrier/pembawa penyakit, seorang yang sakit. Kategori pertama adalah seorang yang sehat, yaitu orang yang tidak membawa sifat sakit, dan tidak ada bahaya untuk keturunannya jika ia menikah dengan seseorang yang sakit, atau pembawa atau dengan orang yang sehat. Kategori kedua adalah seorang yang pembawa sakit, tidak terlihat padanya tanda-tanda sakit. Orang seperti ini dapat menikah dengan orang sehat, dan keturunannya akan menjadi sehat, namun sangat bahaya baginya menikah dengan seseorang yang sakit dengan seseorang yang pembawa sakit. Kategori terakhir adalah orang yang telah terkena sakit, dan tampak padanya tanda-tanda sakit. Orang dengan jenis kategori ini dapat menikah dengan orang yang sehat dan melahirkan keturunan sehat, namun berbahaya menikah dengan orang yang sakit juga ataupun pembawa sakit.

Tes kesehatan ini memiliki fungsi dan tujuan seperti yang dinaskan oleh lembaga yang berwenang di Kuwait. Tes kesehatan pra nikah ini mengeliminasi penyebaran penyakit-penyakit yang menular atau penyakit karena sebab genetika, baik dengan cara berobat dan menjauhkan diri sebelum terjadi penyakit tersebut. Di samping itu, bertujuan untuk membentuk pernikahan yang sehat, dan berketurunan yang sehat pula. Menjadikan hidup menjadi lebih hemat baik dalam hal harta ataupun tenaga, karena telah diketahui lebih dahulu penyakit-penyakit yang mungkin muncul sebelum terjadi menjadi salah satu fungsi tes ini. Pemerintah berperan aktif mensosialisasikan program pernikahan yang sehat yaitu dengan cara menikah dengan orang-orang yang sehat, tidak membawa penyakit, atau jika membawa penyakit maka telah dikonsultasikan sebelumnya kepada dokter hingga dilakukan pengobatan supaya tidak berpengaruh kepada keturunan. 
Untuk pelaksanaan atau tata cara tes kesehatan ini, maka sesuai dengan Peraturan Menteri dengan No. 96 Tahun 2009, maka bagi kedua calon mempelai harus melakukan hal-hal procedural, yaitu:

a. Keduanya pergi ke kantor urusan pernikahan, dalam istilah kita adalah KUA, di sini mereka mengisi formulir bahwa mereka hendak menikah.

b. Kantor urusan pernikahan menerbitkan surat permohonan cek up kesehatan sebelum menikah ditujukan kepada Kementrian Kesehatan.

c. Kedua mempelai membawa surat permohonan cek up kesehatan ke klinik yang telah ditunjuk untuk melakukan tes kesehatan.

d. Surat keterangan kesehatan diterbitkan setelah minimal 5 hari kerja terhitung dimulainya tes kesehatan.

Selanjutnya, jika telah melakukan tes kesehatan dengan spesifikasi yang ditentukan, maka surat keterangan safe married atau unsafe married akan diterbitkan untuk pendaftar, dan surat ini berlaku selama 6 bulan, sehingga kedua calon yang hendak menikah segera melakukan pernikahan setelah terbitnya surat tersebut. Jika ternyata pada salah satu calon terdapat keterangan tidak fit, maka tidak menjadi paksaan untuk tidak menikah, namun keputusan tetap dikembalikan kepada keduanya. Jika tetap hendak melangsungkan pernikahan, maka mereka harus menuliskan surat pernyataan pertanggungjawaban yang menerangkan bahwa mereka telah mengetahui hasil dari cek up kesehatan tersebut. Hal ini jelas pada teks pasal kedua: Bagi pihak KUA atau yang berwenang tidak boleh mencatat perkawinan hingga calon pengantin menyerahkan surat keterangan yang tersebut pada pasal pertama. Jika hasil dari surat keterangan ternyata tidak fit, maka wajib melampirkan pula surat pernyataan persetujuan dari kedua calon bahwa keduanya mengetahui hal ini. Dan persetujuan wali tidak sah jika si calon belum mencapai usia "al rusyd'. Dari pasal ini pula, diketahui bahwa wali tidak dapat mewakili seorang calon yang belum berumur. Namun keputusan harus dikembalikan kepada calon mempelai.

Data di lapangan sesuai yang diberitakan Koran al-Rai pada tahun 2014, hasil check up kesehatan sebelum nikah adalah merupakan hasil yang negatif sebanyak 40 kasus dari keseluruhan pendaftar check up yang hendak menikah adalah 12.214 orang. Dan dari 40 kasus tersebut, mayoritas mereka tidak melanjutkan pernikahan, hanya berhenti sebatas proses ta'aruf saja. Hal ini terjadi mayoritas mereka sudah memahami akan kondisi ini sehingga lebih mementingkan kemaslahatan menjaga keturunan mereka (http://www.alraimedia.com/Home/Details?id=f77ce31e-95d8-4769-977bdb935276270d, dan http://www.alanba.com.kw/kottab/hindalshomer/717238/27-01-2017-الفحص_الطبي_قبل_الزواج). Disamping itu sensus 
kelahiran pada bayi yang lahir pada tahun 2013 di Kuwait, kesemuanya tidak ada yang terkena penyakit thalassemia, hal ini terjadi karena praktek peraturan tes kesehatan sebelum nikah di Kuwait. 80\% dari mereka yang mau nikah menerima tes kesahatan sebagai salah satu syarat prosedur pernikahan dikarenakan tingkat pendidikan yang tinggi, sehinnga meningkat pula kesadaran dalam hal ini. Data dilapangan pula terjadi peningkatan pelayanan, dimana pada awalnya tes ini membutuhkan waktu selama 5 hari aktif, maka menjadi 3 hari aktif untuk mempercepat proses. Dan dalam hal ini Negara Kuwait menjadi Negara tercepat pertama di antara Negara teluk yang lain, dalam proses terbitnya sertifikat cek up kesehatan sebelum nikah (https://www.alanba.com.kw/ar/kuwait-news/health/515334/23-11-2014-

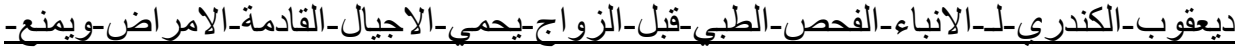

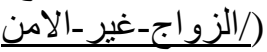

\section{Tes Kesehatan Pra Nikah: Upaya Tindakan Preventif Dalam Bingkai Maqāṣid}

Tes kesehatan pra nikah "Pre-marital Health Screening" merupakan salah satu tindakan preventif menjaga keturunan dari hal-hal yang tidak diinginkan. Tindakan ini meliputi pengecekan penyakit keturunan, atau penyakit menular dengan tujuan menghindari dari resiko yang muncul pada keturunan mereka. Dewasa ini tindakan ini sangat dibutuhkan dikarenakan sebagai salah satu solusi dan sarana meminimalisir jumlah anak yang lahir dengan penyakit turunan dan menular (Rahman MM, 2014: 103). Rangkaian tes yang dilakukan di Kuwait sebagaimana yang telah disebutkan adalah: HIV, Hepatitis B, Hepatitis C, Thalasemia, dan Penyakit Sel Sabit. Penyakit ini merupakan penyakit yang banyak penyebarannya di dunia.

Indonesia termasuk salah satu negara dengan angka penderita thalassemia yang tinggi. Berdasarkan data dari Lembaga Eijkman angka kejadian thalassemia $-\alpha$ di Indonesia sekitar 2,6-11\%, banyak ditemukan di Pulau Sulawesi, yaitu pada suku Bugis ataupun suku Kajang. Sedangkan thalassemia $-\beta$, ditemukan rata-rata sekitar $3-10 \%$, dengan pembawa sifat terbanyak ditemukan di P. Sumatera, dan sekitar hampir 10\% di daerah Palembang. Di Pulau Jawa angka pembawa sifat sebesar 5\%. Sedangkan untuk kelainan hemoglobinopati, pembawa sifat hemoglobin E ditemukan sebesar 1,5-33\% dan terbanyak didapatkan di Pulau Sumba. Adapun penyakit thalassemia, Menurut dr Pustika Amalia Wahidayat, $\operatorname{SpA}(\mathrm{K})$, dokter dari Departemen Hematologi-Onkologi Ilmu Kesehatan Anak Rumah Sakit Cipto Mangunkusumo Jakarta, bahwa penyebaran penyakit thalasemia biasanya cenderung terjadi pada orang-orang warga Italia, Yunani, Timur Tengah, Asia dan Afrika. Namun, di Indonesia sendiri diperkirakan jumlah penderita 
thalasemia bakal mencapai 20 hingga 25 ribu orang pada tahun 2028. Perkiraan ini berdasarkan data Riset Kesehatan Dasar Kemenkes tahun 2015 yang menyebutkan bahwa jumlah penderita Thalasemia adalah 7.029 orang, sehingga terjadi peningkatan sebanyak 1500an kasus pada tahun 2014 yang berjumlah 6.647 kasus.

Para pakar menjelaskan jika penderita thalasemia mayor menikah dengan orang normal, kemungkinan atau probabilitas anaknya 100 persen adalah carrier/pembawa sifat. Sebaliknya, jika seorang penderita thalasemia minor menikah dengan orang sehat dan normal, probabilitas 50 persen anaknya sehat dan menjadi 50 persen thalasemia minor. Sedangkan jika penderita thalasemia minor menikah dengan thalasemia minor, maka 25 persen kemungkinan anaknya akan mengalami thalasemia mayor, kemungkinan 25 persen adalah anak sehat dan kemungkinan 50 persen lainnya anak akan mengalami thalasemia minor. Oleh karena itu, masih menurut para pakar tindakan pencegahan paling efektif untuk memutus mata rantai keturunan thalasemia adalah pertama dengan cara skrining dan kedua yaitu dengan cara mencegah menikah antara pasangan yang keduanya samasama pembawa sifat (https://www.republika.co.id/berita/nasional/umum/18/05/08/p8dnje383kemenkes-kasus-thalasemia-di-indonesia-meningkat).

Tes kesehatan pra nikah seperti yang telah disebutkan di atas akan mengecek penyakit HIV/AIDS juga. Salah satu penyakit yang telah tersebar di dunia dalam jumlah yang sangat banyak. HIV atau Humon Immunodeficiency Virus adalah virus yang menyerang daya tubuh manusia. Berikutnya menjadi kumpulan gejala penyakit yang menyerang yang disebut AIDS yaitu Acquired Immune Deficiency Syndrome (Infodatin: 1). Sumber data pada Kementrian Kesehatan RI menyebutkan bahwa pada tahun 2013 jumlah penderita HIV 35 juta orang, dengan rincian 16 juta adalah dari golongan perempuan, dan 3.2 jutanya adalah anak-anak dibawah usia 15 tahun. Dengan jumlah kematian akibat AIDS pada tahun yang sama adalah 1.5 juta dengan rincian 1.3 juta adalah golongan dewasa, sedangkan sisanya adalah anak-anak dibawah usia 15 tahun (Infodatin: 1). Sementara hasil laporan yang dilaporkan oleh Kementrian Kesehatan menyebutkan bahwa sejak ditemukan pada tahun 1987 hingga Maret 2016, HIV AIDS tersebar di 407 kabupaten/kota, yaitu 80\% dari seluruh jumlah kabupaten/kota di seluruh provinsi di Indonesia.

Sedangkan Hepatitis tidak hanya menjadi masalah di Indonesia saja, namun merupakan masalah dunia. Virus Hepatitis B sendiri telah menginfeksi sebanyak 2 milyar orang di dunia, dengan detail sekitar 240 juta adalah penderita Hepatitis B kronik, dan 170 juta orang dengan penderita C. Sebanyak 1.5 juta orang meninggal dunia setiap tahunnya karena virus ini. 
Virus ini seperti fenomena gunung es, dimana penderita yang tercatat jauh lebih sedikit daripada penderita sesungguhnya. Dikarenakan seringkali orang yang telah terinfeksi terlihat masih sehat dan belum menunjukkan gejala ataupun tanda yang khas, namun penularan tetap berjalan (Infodatin: 3). Memang disini tidak semua jenis penyakit menular dan penyakit genetic yang akan dicek namun beberapa jenis penyakit yang sangat berbahaya, dikarenakan pengecekan semua jenis disini tidak memungkinkan. Namun pengecekan hanya terkait dengan penyakit yang berbahaya yang dimungkinkan dapat muncul dengan pernikahan. Dan di sini lah peran cek up kesehatan sebelum pernikahan sangat penting. Dari data yang diambil dari pusat data dan informasi kemenkes menunjukkan bahwa secara nasional pada tahun 2013 diperkirakan 1.2\% penduduk Indonesia mengidap Hepatitis. Dimana angka tersebut adalah naik dua kali lipat disbanding pada tahun 2007 yaitu sekitar 0.6\%. Jika dikonversikan ke dalam angka maka dari sekitar 2.981.075 jiwa dari 248.422.956 jumlah penduduk Indonesia tahun 2013 terinfeksi penyakit hepatitis (http://www.pusdatin.kemkes.go.id/article/view/15073000001/w-a-s-p-a-d-a2-9-juta-lebih-penduduk-indonesia-mengidap-hepatitis.html).

Dari sini diketahui bahwa tingkat beberapa penyakit yang menjadi obyek check up kesehatan pra-nikah dengan angka yang tinggi dan selalu naik. Sehingga dapat menjadi salah satu rujukan kebijakan bagi para pemangku kebijakan yaitu supaya check up kesehatan dapat dijadikan salah satu alternatif untuk pencegahan penularan penyakit baik kepada pasangan ataupun kepada keturunan. Aiman Muhammad Ali menyebutkan bahwa check up kesehatan sebelum nikah memiliki urgensi ataupun nilai-nilai positif jika dilakukan, diantaranya yaitu: bahwa cek kesehatan sebelum nikah ini sangat memperhatikan sisi kesehatan pada anak-anak yang akan menjadi keturunannya sehingga keturunan yang lahir adalah keturunan yang sehat baik secara ruhani ataupun jasadi, hal ini merupakan salah satu tujuan atau maqashid syariah "menjaga keturunan". Di samping itu tes kesehatan sebelum nikah adalah tindakan preventif yang sangat efektif untuk meminimalisir penyebaran penyakit genetik ataupun penyakit menular yang bahaya, tambahnya. Pada cek kesehatan sebelum nikah pun juga akan dilakukan pengarahan-pengarahan kesehatan bagi suami istri yang dapat membawa kepada pernikahan yang bahagia, terlepas dari bahaya kesehatan yang mencekam (Aiman Muhammad Ali Hatmal, 2016: 299). Kebijakan ini dapat mencontoh dari adanya peraturan perundang-undangan yang telah ada di berbagai Negara, salah satunya yaitu di Negara Kuwait, dari data disebutkan bahwa sensus kelahiran bayi pada tahun 2014 semua bayi yang lahir tidak ada yang terkena kasus thalassemia, yang sempat menjadi momok 
Negara tersebut (http://www.alanba.com.kw/kottab/hindalshomer/717238/27-01-2017-الزواج-ق بل-ال ط بي-ال فحص//k).

Jika dikaitkan dalam konteks keindonesiaan, maka menengok di banyak Negara, Indonesia dapat belajar kepada Negara-negara yang telah menerapkan hal ini. Selain Kuwait, yang telah disebutkan pada bab sebelumnya, Undang-Undang Negara Jordan juga telah mengadopsi peraturan ini, di mana peraturan cek up kesehatan pra-nikah ini memiliki beberapa tujuan: Pencegahan terjadinya penyakit genetic, khususnya penyakit Thalasemia. Hal ini dapat diketahui dengan memeriksa calon pasangan jika mereka adalah pembawa 'carrier' penyakit ini, jika memang demikian kondisinya maka memberikan konsultasi kesehatan untuk mereka tentang kemungkinan keturunan jika terjadi kehamilan. Bahwa Thalasemia adalah penyakit yang penyebarannya terjadi secara massif di Negara ini, dan penyakit ini oleh para dokter mungkin dihindari yaitu sebelum terjadinya pernikahan (Faruq Badran, 1994: 97-98). Karena kondisi yang berbeda-beda untuk tiap Negara, maka penerapan untuk Indonesia dapat dilihat penyakitpenyakit dengan angka penyebaran yang tinggi, dimana pemerintahan suatu Negara ingin melakukan pencegahan dalam skala yang lebih besar lagi. Jika di Kuwait, lalu juga Jordan melalakukan tes ini, dan thalassemia menjadi salah satu obyeknya, maka karena penyakit ini menyebar begitu besar, namun dalam konteks keindonesiaan secara umum dapat mengadopsi tes kesehatan ini namun dengan obyek dan ketentuan berbeda, walaupun secara umum thalassemia juga dapat diikutkan dikarenakan angkanya yang semakin meninggi pula untuk kasus di Indonesia.

Walaupun dalam kenyataannya dirasa terdapat bahaya-bahaya yang mungkin timbul, namun secara medis mengarahkan pentingnya cek kesehatan pra-nikah untuk penyakit-penyakit tertentu, karena mengecek secara keseluruhan penyakit tidak memungkinkan, membutuhkan energy yang luarbiasa, disamping finansial yang sangat tinggi. Tes kesehatan ini dipelakukan bagi mereka yang hendak menikah, dan di sini penting sekali untuk menggunakan adab-adab medis: memberikan konsultasi medis, tidak menyebarkan hasil rekaman medis, memberikan pengobatan pada penyakitpenyakit yang sekiranya dapat diobati sebelum pasangan melakukan pernikahan. Terkait dengan urgensi tes ini, para ulama' kontemporerpun ikut berkomentar, dan memberikan tanggapan positif, walaupun dalam pelaksanaanya dirasa ada beberapa kemadharatan, namun maslahat yang didapat adalah maslahat yang lebih kuat. Menukil pendapat Muhammad Usman Syabir bahwa tes ini akan menjadikan keluarga menjadi lebih langgeng daripada rumah tangga yang dibangun dari pasangan yang sakit. Adapun pelaksanaanya maka dapat diatur sedemikian rupa sehingga tidak 
meninggalkan efek negative bagi pelakunya, baik laki-laki ataupun perempuan (Muhammad Usman Syabir, 1416 H: 210).

Cek kesehatan sebelum nikah salah satu tujuannya yaitu membentuk keluarga dan keturunan yang sehat, sehingga termasuk salah satu prinsip Maqāșid al-Sharī'ah dalam cakupan ḍarūriyyāt atau level pertama pembagian Maqāșid al-Sharī’ah jika ditinjau dari segi kemaslahatannya. ḍarūriyyāt ini adalah lima asas pokok penting dalam syariat Islam. Kelima hal ini adalah: Pemeliharaan terhadap agama, jiwa, akal, harta dan keturunan yang terkenal dengan julukan Al-kulliyyāt al-khamsah. Pada dasarnya pernikahan yang bahagia adalah pernikahan yang dapat terealisasi didalamnya tujuan-tujuan mulia dalam Islam, diantaranya adalah terbentuknya keturunan yang berkualitas, lahirnya generasi yang sehat sehingga terbentuk pula kehidupan bermasyarakat dalam ikatan yang kuat dan harmonis. Dan untuk tujuan ini Islam mengatur dalam pemilihan calon suami istri yang baik, dan sehat untuk memelihara keturunan. Jika salah satu pasangan adalah pasangan yang sakit, berpenyakit penyakit menular atau penyakit genetic bahaya, ini akan dapat membawa kepada penularan kepada anak keturunan ataupun kepada pasangannya yang bisa jadi mengakibatkan ketidak-harmonisan dalam rumah tangga yang menjadi salah satu akibat lahirnya perceraian dalam rumah tangga (Aiman Muhammad Ali Hatmal: 308).

Check up kesehatan merupakan salah satu penerapan yang berstatus ijtihādiyyah, dimana secara praktek dan penerapannya disesuaikan dan ditentukan berdasarkan kebutuhan dan kemaslahatan. Penerapannya dapat bersifat mengikat bila pemerintah dalam hal ini ikut berperan serta, baik dalam tataran pembentukan perundang-undangan ataupun wewenang dan kewajiban memberikan fasailitas bagi warganya menuju rumah tangga yang sehat. Jika dilihat dari data-data yang ada tentang penyakit-penyakit keturunan, khususnya thalassemia, maka penulis merasa penting saat ini sekiranya jika pemerintah mengambil kebijakan untuk menerapkan check up kesehatan sebelum nikah bagi mereka yang hendak menikah, sebagai rangkaian persyaratan secara administrasi, yang dampaknya akan kembali kepada pasangan suami-istri, dimana mereka adalah unsur terkecil dalam masyarakat. Jika keluarga sehat, maka akan menjadikan masyarakat sehat, berikutnya akan menjadi sebuah tatanan Negara yang sehat pula. Meskipun memang cek kesehatan ini tidak termasuk bagian dari syarat ataupun rukun secara fiqih, namun pemerintah sebagai ulul amri dapat menjadikannya sebagai salah satu syarat pernikahan, dengan mengacu kepada Negara-negara yang telah mempraktekkannya, dan tentu dengan melihat kondisi di Indonesia. Seperti halnya pencatatan perkawinan tidak pernah ada dalam era dulu, karena bergantinya situasi sehingga masa sekarang ini pemerintah mewajibkan pencatatan perkawinan dalam rangka menjaga hak-hak pasangan 
suami istri. Dalam cek kesehatan pra nikah sebagai salah satu syarat untuk menikah termasuk bagian daripada kewenangan ulum amri yang sesuai dengan kemaslahatan rakyat, sesuai dengan kaidah fiqih: "Tindakan terhadap rakyat harus sesuai dengan dengan kemaslahatan" (Ade Dedi Roahayana, 2008: 139).

\section{Kesimpulan}

Berdasarkan paparan di atas, maka dapat disimpulkan beberapa hal di bawah ini:

Di Indonesia, masalah kesehatan dalam persiapan pernikahan tidak menjadi perhatian khusus, disamping tidak adanya Undang-Undang yang mengatur tentang persiapan pernikahan dari segi kesehatan, baik UndangUndang Perkawinan ataupun Kompilasi Hukum Islam, namun telah diterapkan Imunisasi Tetanus Toksoid bagi calon pengantin wanita dengan tujuan setiap calon pasangan wanita ataupun bayi yang akan dilahirkannya kelak terbebas dari infeksi tetanus. Hanya saja imunisasi atau vaksin jenis ini hanya dapat mencegah infeksi Tetanus, TBC, Differi, Batuk Rejan dan Campak dan tidak bisa untuk mengetahui riwayat kesehatan calon pasangan dan penyakit menular seksual dan keturunan, seperti HIV/AIDS dan Thalasemia yang semakin mewabah di masyarakat kita.

Tes kesehatan pra-nikah ini telah dilaksanakan di banyak Negara. Di Kuwait sendiri, tes ini telah dilaksanakan berdasarkan pada UU No. 31 Tahun 2008, yang merupakan salah satu seperangkat penguat dari UU No. 51 Tahun 1984 tentang Hukum Keluarga di Kuwait. UU No. 31 Tahun 2008 ini terdiri dari 6 pasal saja. Perundangan ini pada dasarnya telah disetujui oleh Majlis al-Ummah sejak bulan November 2008, namun baru dapat dipraktekkan pada bulan Agustus pada tahun berikutnya, 2009 . Namun hasil dari tes kesehatan ini bersifat tidak mengikat, dalam artian, jika hasil dari surat keterangan ternyata pasangan tidak fit untuk menikah, namun mereka tetap ingin melanjutkan, maka wajib melampirkan pula surat pernyataan persetujuan dari kedua calon bahwa keduanya mengetahui hal ini.

Check up kesehatan merupakan salah satu penerapan yang berstatus ijtihādiyyah maka memberi ruang terhadap proses pembentukan hukumnya yang dapat berubah tergantung dinamika sosial dan fenomena yang terjadi. Sehingga secara praktek dan penerapannya disesuaikan dan ditentukan berdasarkan kebutuhan dan kemaslahatan. Penerapannya dapat bersifat mengikat bila pemerintah dalam hal ini ikut berperan serta, baik dalam tataran pembentukan perundang-undangan ataupun wewenang dan kewajiban memberikan fasilitas bagi warganya menuju rumah tangga yang sehat. 


\section{Daftar Pustaka}

\section{Pustaka yang berupa jurnal ilmiah:}

Andriyaldi. (2014). Teori Maqashid al-Syariah Menurut Perspektif Imam Muhammad Thahir bin 'Asyūr. Islam dan Realitas Sosial, Vol 7(1), Januari-Juni.

Arif Ali Arif. (1999). Al-Ikhtibār al-jiniy wa al-Wiqāyah min al-Amrādh alWirāthiyyah Min al-Mandzūr al-Islāmiy. Majallat al-Tajdīd. Malaysia: Penerbit IIUM, edisi 5, tahun III.

Fahad M Alswaidi and Sarah JO'Brien. (2009). Premarital screening programmes for haemoglobinopathies, HIV and hepatitis viruses: review and factors affecting their success. Journal of Medical Screening, Vol 16(1).

Hanan Abd Elfatt, dkk (2015). Premarital Genetic Counselling among Female Adolescents Students. Journal of American Science Vol 11(6).

Hatmal, Aiman Muhammad Ali. (2016). al-Fahșu al-Ṭibby Qobla al-Zawāj Ṭibbiyyan wa Shar'iyyan wa Qānūniyyan. Jurnal Majallah al-Quds al-Maftūhah, Vol 41(2). 299.

Munawaroh, Lathifah. (2017). Harmonisasi Antar Umat Beragama Melalui Pernikahan Beda Agama. Jurnal Fikrah. Vol 5(1).

Rahman MM, dkk. (2014). PREMARITAL HEALTH SCREENING - A REVIEW AND UPDATE. Jurnal JAFMC Bangladesh. Vol 10(1).

\section{Pustaka yang berupa judul buku:}

Abdurrahman bin Sholih. (2003). al-Qawāid wa al-Dhawābith al-Fiqhiyyah al-Mutadamminah li al-Taysìr. cMadinah: Lembaga penerbitan pada Universitas Madinah.

Abu Zahra, Muhammad. (1957) al-aḥwāl al-shakhșiyyah. Kairo: Dār al-Fikr al-'Arabi. 
Tes Kesehatan Sebagai Syarat Pra Nikah

Al-Asyqar, Umar Sulaiman. (2005). al-Madkhal ilā al-shari'ah wa al-Fiqh al-Islāmi. Jordan: Dār al-Nafāis.

Ayyub, Syaikh Hasan. (2001). Fikih Keluarga, terj. Abdul Ghofar. Jakarta: Pustaka al-Kautsar.

Azzam, Abdul Aziz Muhammad dan Sayyed Hawwas, Abdul Wahhab. (2009). Fiqh Munakahat, terjm. Abdul Majid Khon. Jakarta: Imprint Bumi Aksara.

Bin Hajjaj, Muslim. (t.th.) Shahih Muslim. Beirut: Dar Ihya' Turats alArabiy.

Al-Bukhori, Muhammad bin Ismail. (1422 H) Shohīh Al Bukhori. Mesir: Dar Thouq najah.

Darajat, Zakiyah, dkk. (1985). Ilmu Fikih. Jakarta: Departemen Agama RI.

Dariyo, Agoes. (2003). Psikologi Perkembangan Dewasa Muda. Jakarta: PT. Gramedia Pustaka Utama.

Ghozali, Abdul Rahman. (2010). Fiqih Munakahat. Jakarta: Kencana.

Al-Hushoni, Abu Bakar bin Muhammad. (1994). Kifāyat al Akhyārr. Damaskus: Dar al khoir.

Ibnu Abdi al-Salam, Izzuddin. (t.th). Qawāid al-Ahkām. Beirut: Dar al-Kutub al-Ilmiyyah.

Ibnu Asyur, Thahir. (2004). Maqāshid al-Sharīah al-Islamiyyah. Qatar: Wizārat al-Awqāf.

Kuzari, Ahmad. (1995). Nikah Sebagai Perikatan. Jakarta: Rajawali Pres.

Al-Māwardi, Ali bin Muhammad. (1999). Al Hāwi Al Kabīr. Beirut: Dar al kutub al ilmiyyah.

Nurudin, Amiur dan Azhari Akmal. (2006). Hukum Perdata Islam di Indonesia. Jakarta: Kencana Prenada Media Grup.

Rafiq, Ahmad. (1998). Hukum Islam di Indonesia. Jakarta: Rajawali press.

Yudisia Vol. 10 No. 1, Juni 2019 
Al-Raisuni, Ahmad. (1992). Nazāriyyat al-Maqāṣid 'inda al-Imām alShātịi, t.tp: Dār al-Kitāb al-Islāmiy.

Ramulya, Idris. (1996). Hukum Perkawinan Islam: Suatu Analisis dari Undang-Undang No. 1 Tahun 1974 dan Kompilasi Hukum Islam. Jakarta: Bumi Aksara.

Rohayana, Ade Dede. (2008). Ilmu Qawā'id Fiqhiyyah. Jakarta: Gaya Media Pratama.

Sabiq, Sayyid. (1983). Fiqh Sunnah. Beirut: Dar al-Fikr.

Al-Șan'ani, Alauddin Abu Bakar bin Mas'ud. (1986). Badā'I al Șanā'I. Beirut: Dar al kutub al ilmiyyah.

Șālih bin Muhammad. (2000). Majmū'at al-Fawāid al-Bahiyyah 'alā Nudzum al-Qawā'id al-Fiqhiyyah. KSA: Dār al-Sumai'iy.

Syarifudin, Amir. (2014). Hukum Perkawinan Islam di Indonesia. Jakarta: Prenadamedia Grup, cet.5.

Al-Shāṭibi, Abū Isḥāq. (1997). al-Muwāfaqāt fi Ușūl al-Sharīah, t.tp: Dār Ibnu Affān.

Al-Syirbīni, Muhammad bin Ahmad al-Khațīb. (t.th). Al Iqnā' fì hilli alfädz abì Syujā'. Beirut; Dar al fikr.

Tihami dan Sohari. (2014). Fiqih Munakahat: Kajian Fiqih Nikah Lengkap, Jakarta: Rajawali Press.

Al-Tirmīdzī, Muhammad bin Īsā. (1975). Sunan Al-Tirmīdzī. Mesir: Mustafāā al bābi al halabi.

Yafie, Ali. (1982). Pandangan Islam terhadap Kependudukan dan Keluarga Berencana. Jakarta: Lembaga Kemaslahatan Keluarga NU dan BKKBN.

Al-Zuhaily, Wahbah. (1989). al-Fiqh al-Islāmy wa adillatuhū. Damsyiq: Dār al-Fikr. 
Tes Kesehatan Sebagai Syarat Pra Nikah

\section{Pustaka yang berupa judul Perundang-undangan:}

Undang-Undang Dasar Kuwait, al-Dustūr al-Kuwaity dalam Majmū'at alTashrīât al-Kuwaitiyyah, diterbitkan oleh Kementrian Kehakiman, 2011.

Qānūn al-Aḥwāl al-Shakhṣiyyah dalam Majmū'at al-Tashrī'āt alKuwaitiyyah, diterbitkan oleh Kementrian Kehakiman, 2011.

Undang-Undang No. 31 Tahun 2008, Kuwait, tentang cek up kesehatan sebelum nikah.

\section{Pustaka yang berupa Sumber Internet:}

https://www.kuwait-history.net/vb/showthread.php?t=1778 diunduh pada tgl 26/6/2018 jam 09.00.

https://alqabas.com/165374/ diunduh pada tgl 26/6/2018 jam 09.00.

https://www.alanba.com.kw/ar/kuwait-news/health/515334/23-11-2014-

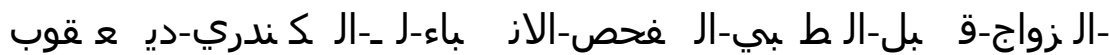

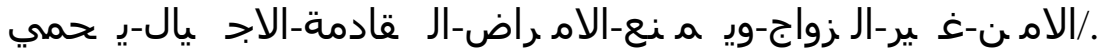
Diunduh pada tanggal 30/8/2018, jam 08.06.

http://www.alraimedia.com/Home/Details?id=f77ce31e-95d8-4769-977bdb935276270d, pada tanggal 28 Agustus 2018, jam 14.54.

http://www.alanba.com.kw/kottab/hind-alshomer/717238/27-01-2017-

الزواج-ق بل-ال ط بي-ال فحص pada tanggal 28 Agustus 2018, jam 14.54 .

https://www.alanba.com.kw/ar/kuwait-news/health/515334/23-11-2014-

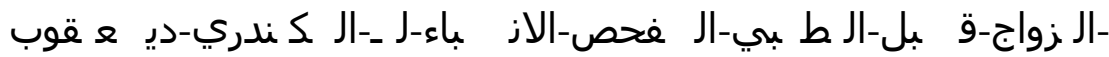

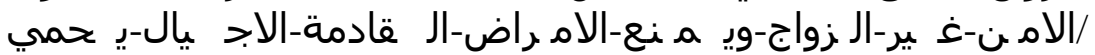
diunduh pada tanggal 28 Agustrus 2018, jam 15.00.

https://www.liputan6.com/health/read/2945112/jumlah-pasien-thalasemia-diindonesia-capai-25-ribu-pada-2028, diunduh pada 15 agustus 2018, jam 11.27. 
https://www.republika.co.id/berita/nasional/umum/18/05/08/p8dnje383kemenkes-kasus-thalasemia-di-indonesia-meningkat, diunduh pada 15 Agustus, jam 11.45.

http://www.pusdatin.kemkes.go.id/article/view/15073000001/w-a-s-p-a-d-a2-9-juta-lebih-penduduk-indonesia-mengidap-hepatitis.html. Diunduh pada $21 / 8 / 2018$ pukul 14.36 .

\section{Pustaka yang berupa Sumber Buku Laporan:}

Laporan Perkembangan HIV-AIDS \& PIMS di Indonesia Januari-Maret 2017, diterbitkan Ditjen P2P, Kementrian Kesehatan RI 2017.

Data Statistika Negara Kuwait Tahun 2015, diterbitkan oleh Labor Market Information Sistem, Negara Kuwait.

Infodatin: Pusat Data dan Informasi Kementrian Kesehatan RI, Situasi dan Analisis HIV AIDS.

Infodatin: Pusat data dan informasi Kementrian Kesehatan RI, Situasi dan Analisis Hepatitis, h. 1-2. Di unduh http://www.depkes.go.id/folder/view/01/structure-publikasi-pusdatininfo-datin.html. pada 21/8/2018, pukul 14.15. 